\title{
Effect of Heavy Metal Contamination on Soil Enzymes Activities
}

\author{
Justice Ofori Yeboah, Guangyu Shi, Weilin Shi* \\ Department of Environmental Science and Engineering, Suzhou University of Science and Technology, Suzhou, China \\ Email: oforiyeboahjust@gmail.com, shigylove@126.com, *shi@163.com
}

How to cite this paper: Yeboah, J. O., Shi, G. Y., \& Shi, W. L. (2021). Effect of Heavy Metal Contamination on Soil Enzymes Activities. Journal of Geoscience and Environment Protection, 9, 135-154. https://doi.org/10.4236/gep.2021.96008

Received: May 25, 2021

Accepted: June 25, 2021

Published: June 28, 2021

Copyright $\odot 2021$ by author(s) and Scientific Research Publishing Inc. This work is licensed under the Creative Commons Attribution International License (CC BY 4.0).

http://creativecommons.org/licenses/by/4.0/

\section{(c) (i) Open Access}

\begin{abstract}
Several enzymes catalyze much of the processes that exist in the soil. Enzymes in polluted soils are usually less active due to their exposure to heavy metals. The main goal of this study was to see how bioavailable types of $\mathrm{Cd}$ affected the behavior of catalase, urease, and dehydrogenases, as well as to compare the findings from naturally and artificially polluted samples. An experiment was conducted on two types of farmland (garden) soil: natural soil and soil that had been chemically polluted with $\mathrm{Cd}$. The total content of heavy metal graded these soils as very highly polluted with $\mathrm{Cd}$. The experiment was repeated four times to test the effects of increasing concentration and days (time). Extracellular enzymes from farmland performed enzymatic activity tests that lasted 6 to 29 days after soil sampling. After 0, 5, 10, 20, 30, and 45 days of incubation, soil samples were taken for testing respectively. However, even though no nutrient was added, dehydrogenase and urease activity increased as $\mathrm{Cd}$ concentration increased from 0 to $5 \mathrm{mg} / \mathrm{L}$ as the days passed. This is a result of enzymes engaging in respiratory and other living activities because of the low cadmium concentration and respiratory soil properties. However, there were significant variations in enzyme activity between naturally polluted and artificially contaminated soils. Dehydrogenases, Urease, and Catalase all showed a common pattern of enzyme sensitivity, which could be ordered as Dehydrogenase $>$ Urease $>$ Catalase. Dehydrogenase enzyme activity has been discovered to be more Cd resistant.
\end{abstract}

\section{Keywords}

Enzyme Activity, Dehydrogenases, Catalase, Urease, Soil Contamination, Heavy Metal

\section{Introduction}

A substantial percentage of the earth consists of soil that constitutes an essential 
part and component of the ecosystem, which forms the material basis for human and plant existence. As human life, progresses with dramatically increased development and industrialization, heavy metals and soil contamination may continue to spread globally. Heavy metals are a specific group of elements with an atomic density of more than $6 \mathrm{~g} / \mathrm{cm}^{3}$. The global increase in human development is rapidly changing our world and has generated unique soils that vary in contaminant nature and concentration, moisture, and nutrient levels. The process of understanding how soil communities are affected by human impacts includes resolving differences in the structural and functional characterization of the biotic community. Within the soil, the presence and concentration of contaminants will modulate interactions between soil organisms (Fabietti et al., 2010).

Research on soil function, specifically enzymatic activity, in these systems, is an increasingly important approach to a more holistic understanding of soils in contaminated environments. In contaminated soils, the activity of the microbial community is intertwined with soil abiotic properties (Krčmar et al., 2018). Functions like cellulose degradation or nitrogen cycling can be measured by using soil enzymatic activities as indicators (Cofie et al., 2014). When microbial communities adjacent to industrialized sites were analyzed, they showed lower enzymatic function with higher soil metal loads as well as lower community diversity (Ahmad et al., 2018). Lower enzymatic activities have also been observed when the soil was experimentally contaminated with heavy metal loads. For instance, Kandeler et al. (1996) and (1999), showed lower urease, alkaline phosphatase, and xylanase activities for soils experimentally contaminated with $\mathrm{Zn}$, $\mathrm{Cu}, \mathrm{Ni}, \mathrm{V}$, and $\mathrm{Cd}$ compared to soils that were not experimentally contaminated.

However, in other studies, high soil metal loads were associated with high enzymatic activities and in other studies, shifts in the microbial community composition and functioning were found with a metal load. These results highlight the complexity of the effect of heavy metal contamination on soil enzyme activities and the need to consider the experimental details of each study. The goal of this research was to determine the relationship between elevated hazardous element (i.e., cadmium) concentrations in soil and extracellular enzyme activities that are proxy measures for nutrient cycling. The results of this study will help answer an important question relevant to restoration ecology: What are the effects of long-term metal contamination on microbial nutrient cycling in soils?

\section{Material and Method}

\subsection{Site Description}

The primary research site is located near the town of Suzhou (China's Jiangsu Province, Suzhou University of Science and Technology, (latitude N 34 $38^{\prime}$, longitude E $\left.119^{\circ} 38^{\prime}\right)$. The study area is a farmland situated in the warm-temperate, semi-humid, monsoon climate region $\left(222 \mathrm{~m} \cdot\right.$ asl; $\mathrm{T}_{\text {winter }}=8^{\circ} \mathrm{C}-22^{\circ} \mathrm{C}, \mathrm{T}_{\text {summer }}=$ $22^{\circ} \mathrm{C}-42^{\circ} \mathrm{C}$ ); several arboreal species dominated the area, including Moringa oleifera, Nimes plants, Eugenia jambolana, and the plant community is defined by 
temperate, evergreen plants growing in diverse contamination (Cofie et al., 2014).

\subsection{Soil Collection}

Soil samples from the top $0-20 \mathrm{~cm}$. The soil samples from the research region were packed into a light plastic container to the laboratory on ice, sieved with 2-mm mesh, and kept at a temperature of $20^{\circ} \mathrm{C}$ for enzyme assays of catalase, urease, and dehydrogenase activity. Extracellular enzyme activity was measured to determine the degree of enzyme activity as well as whether collected soil was already contaminated with other heavy metals. After the removal of the huge roots, the soil sample was used as control, after which further sampling was carried out with addition of contaminants and the contaminated samples were studied from days 6 to 29 .

The soil properties were as follows: $\mathrm{pH} 6.16$, CEC $17.04 \mathrm{CMoL} \cdot \mathrm{kg}^{-1}$, organic matter $40.05 \mathrm{~g} \cdot \mathrm{kg}^{-1}$, N $0.77 \mathrm{~g} \cdot \mathrm{kg}^{-1}, \mathrm{P} 10.32 \mathrm{mg} \cdot \mathrm{kg}^{-1}$, and $\mathrm{K} 71.93 \mathrm{mg} \cdot \mathrm{kg}^{-1}$. rough particulates are first separated after natural air-drying and then screened through 100 mesh for standby. The soil sample was inspected over several days for effective data correctness, other analytical mistake was taken into consideration, as well as being separated into three independent samples to ensure no conflicting changes, with rises or declines in enzymatic activities during assays procedure. Cd with a background of $0.27 \mathrm{mg} \cdot \mathrm{kg}^{-1}$. $\mathrm{Cd}\left(\mathrm{NO}_{3}\right)_{2}$ was used to prepare the heavy metal salt solution.

Semi-micro Kjeldahl methodology was applied to determine nitrogen. The sulfuric acid-per-chloric acid digestion method was used to quantify total phosphoric acid, and organic matter determines by the $\mathrm{K}_{2} \mathrm{Cr}_{2} \mathrm{O}_{7}$ volumetric method. The concentrations of $\mathrm{Cd}$ in dispelled soil samples was determined using the complete decomposition method and flame atomic absorption spectrophotometry, which never surpass the secondary norm of the "Environmental Quality Standard for Soils" (GB15618-1995) (Cd£0.3 mg/kg) or the first-grade standard of soil environmental quality in Jiangsu Province ( $\mathrm{Cd} £ 0.2 \mathrm{mg} / \mathrm{kg}$ ) (Shi \& Ma, 2017). The concentration of other heavy metals was also determined by AA-7000 atomic absorption spectrophotometer (AAS, Shimadzu, Japan). The solution was mix into the air-dried soil and well mixed. After standing for 45 days, it was used as test soil.

\subsection{Enzyme Activities and Basal Respiration Assays}

As the research commenced other approach of testing enzymes was considered in order to accurately evaluate the efficacy of the enzymes' reactions. The indophenol-based colorimetric method was used to assess soil urease activity, whiles $\mathrm{NH}_{4}^{+}$was release by urease-mediated, the enzymatic hydrolysis of urea was measured calorimetrically at $578 \mathrm{~nm}$ (Guan, 1986; Guan et al., 1986). Dehydrogenase activity is determined by reducing 2,3,5-triphenyl tetrazolium chloride (TTC), extracting the triphenyl formazan (TPF), and measuring as $485 \mathrm{~nm}$ (Guan et al., 1986). Catalase activity was determined using the titration process (Guan et al., 1986), and soil basal respiration (SBR) is determined using the so- 
dium hydroxide absorption method $\left(\mathrm{CO}_{2}\right.$ generation by incubation for 24 hours at $25^{\circ} \mathrm{C}$ ) (Xu et al., 2020).

\subsection{Material and Reagent}

The enzyme solutions to be used are Catalase, Urease, Dehydrogenase activity with different molarity, as the experiment proceeds all these soil enzymes were exposed to cadmium reaction.

\subsubsection{Catalase Activity Determination}

\section{Volumetric method for measuring soil catalase}

The catalase activity was determined using $1.5 \mathrm{~mol} / \mathrm{L} \mathrm{H}_{2} \mathrm{SO}_{4}$ solution, $0.3 \%$ percent $\mathrm{H}_{2} \mathrm{O}_{2}$, a saturated alum solution, and $0.02 \mathrm{~mol} / \mathrm{L}$ potassium permanganate as reagents which was carried by out Zhou \& Zhang (1980).

The experimental steps involve supplementing $2 \mathrm{~g}$ soil in Erlenmeyer flasks $\left(50 \mathrm{~mL}\right.$ ) containing $40 \mathrm{~mL}$ and $5 \mathrm{ml} 0.3 \%$ of distilled water and $\mathrm{H}_{2} \mathrm{O}_{2}$ solution respectively then sealed immediately. The Erlenmeyer flasks were put on the oscillator for (120 r/min). After 20 minutes, $1 \mathrm{ml}$ full-bodied aluminium potassium alum was added and the solution was immediately filtered in the triangle bottle containing $5 \mathrm{ml}$, and later $1.5 \mathrm{~mol}$ sulphuric acid was also added. Subsequently, the solution in the bottle is filtered with quantitative filter paper, $25 \mathrm{ml}$ of the filtrate been absorbed, and titrated to purple red and $0.02 \mathrm{~mol} / \mathrm{L}$ potassium permanganate added. Also, a soil-free control was performed.

\subsubsection{Determination of Urease}

\section{Colorimetric method determination of soil urease}

The solutions used for the Urease activity determination include Citrate solution with a $\mathrm{pH}$ of 6.7 , along with Sodium phenol solution, Sodium hypochlorite solution, $10 \%$ urea solution is also used with a Standard solution of $\mathrm{N}$ as a reagent.

The Experimental steps involve supplementing $5 \mathrm{~g}$ soil in Erlenmeyer flasks $(50 \mathrm{~mL})$ containing $1 \mathrm{ml}$ toluene then gasser plug tightly and shake gently for 15 minutes. $10 \mathrm{~mL}$, was added to $10 \%$ urea solution and $10 \mathrm{~mL}$ citrate buffer $(\mathrm{pH}$ 6.7) and mix carefully within the used bottle. Later put the Erlenmeyer flasks in a constant temperature box at 37 for 24 hours. The suspension is then filtered by diluting the scale with distilled water heated to 38 degrees Celsius (toluene should float above the scale). The suspension is shaken and filtered. The filtrate was then diluted with $20 \mathrm{~mL}$ of distilled water, later sodium phenol solution of 4 $\mathrm{ml}$ was added, and sodium hypochlorite solution of $3 \mathrm{ml}$ was included immediately. Upon adding each reagent, the mixture was shaken immediately. After 20 minutes, the mixture was diluted to the scale and the absorbance was recorded at $578 \mathrm{~nm}$. Urease activity was calculated by subtracting the difference between the absorbance of the control sample and the amount of ammonia nitrogen according to the standard curve. 


\subsubsection{Dehydrogenase Activity Determination}

In a tube with $1 \mathrm{~g}$ of soil sample cultured, $0.2 \mathrm{ml}$ of $3 \%$ sterile triphenyl tetrazolium chloride (TTC) solution and $0.5 \mathrm{ml}$ of $1 \%$ sterile glucose added to assess dehydrogenase activity. Following a 24 -hour incubation time at $28^{\circ} \mathrm{C}, 10 \mathrm{ml}$ of methanol was added as reagents.

In this study, the dehydrogenase procedure includes: $50 \mathrm{ml}$ beaker, $20 \mathrm{~g}$ of fresh soil was combined with $200 \mathrm{mg}$ of dried $\mathrm{CaCO}_{2}$ and brought to $90 \%$ water-holding capacity that contains $2.0 \mathrm{ml}$ of a $1 \%$ TTC mixture. It was completely blended, with the surface tamped keeping the air out. After that, the sample was incubated with a pressurized incubator (R.H., 70) within 24 hours at $30^{\circ} \mathrm{C}$. During the period of incubation, the beaker was filled with a $25 \mathrm{ml}$ volume of methanol and 5 minutes of stirring. The resulting slurry was filtered with successive aliquots of methanol through a Buchner filter (Whatman No. 5 paper). The amount of extractant used for each sample was then recorded.

Using methanol as a reference blank, the coloured density extract was measured spectrophotometrically at a wavelength of 485. Comparisons with a TPF standard curve in methanol were used to measure concentrations. The following equation was used to calculate the amount of hydrogen transmitted as TTC decreases to TPF in $20 \mathrm{~g}$ soil: 2,3,5-triphenyl tetrazolium chloride $+2 \mathrm{H}+$ triphenylformazan + HC1. $150.35 \mathrm{pH}$ is needed to make $1 \mathrm{mg}$ of TPF.

\subsubsection{Soil Amendment and Incubation}

The soil moisture adjusted to $60 \%$ water holding capacity with distilled water incubated at $25^{\circ} \mathrm{C}$ was kept in darkness for 45 days with treatment repeated four times. A stock solution was developed after dissolving $\mathrm{Cd} 2.0 \mathrm{~g} / \mathrm{L}$ in water. In a volumetric flask, dissolve $3.723 \mathrm{~g} \mathrm{Cd}$ sulfate in $1000 \mathrm{~mL}$ water. Cd was applied to soil samples weighing $500 \mathrm{~g}$ at mass concentrations of $0 \mathrm{mg} / \mathrm{kg}$ (control sample), equally distributed of $0.0,0.1,1.0,2,5,10 \mathrm{mg} / \mathrm{L}$ cadmium (II) concentrations of the Cd stock solution were sprayed. After soil amendment and incubation, $10 \mathrm{~g}$ grams of soil with six different levels was thoroughly mixed with $90 \mathrm{~mL}$ distilled water, respectively. $1 \mathrm{~mL}$ of the soil solution was then moved to a $100 \mathrm{~mL}$ conical flask and incubated at $28^{\circ} \mathrm{C}$ for another 15 days. The sample was analyzed and the analytical error was also accounted for and divided into three separate samples. The experiment was carried out in 45 days with the activities and effects recorded.

Data processing; After that, using Microsoft Excel 2010, the data was analyzed and a line error analysis was performed (Figures 1-6). As the experiment went on, there were some errors and data reported. The outcome and data of the experimental processes of different concentrations of cadmium reactions to Catalase, Urease, and Dehydrogenase activity are shown in the diagram in the result and discussion.

\section{Results and Discussion}

The most significant metrics for evaluating and monitoring the effects of soil 


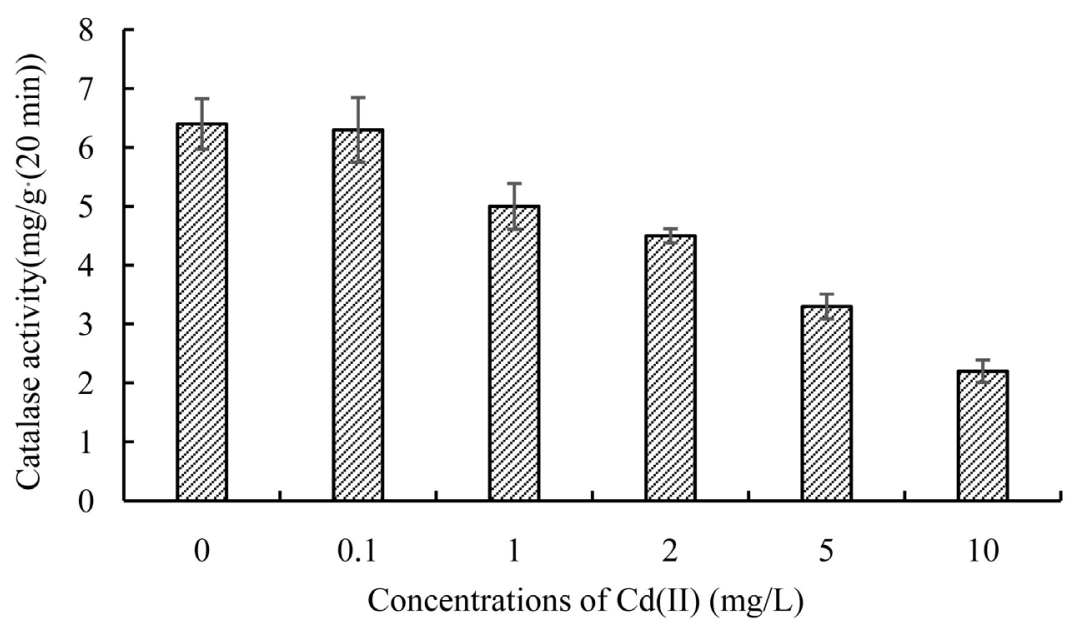

Figure 1. Effect of Cd concentrations on Catalase activity in the soil.

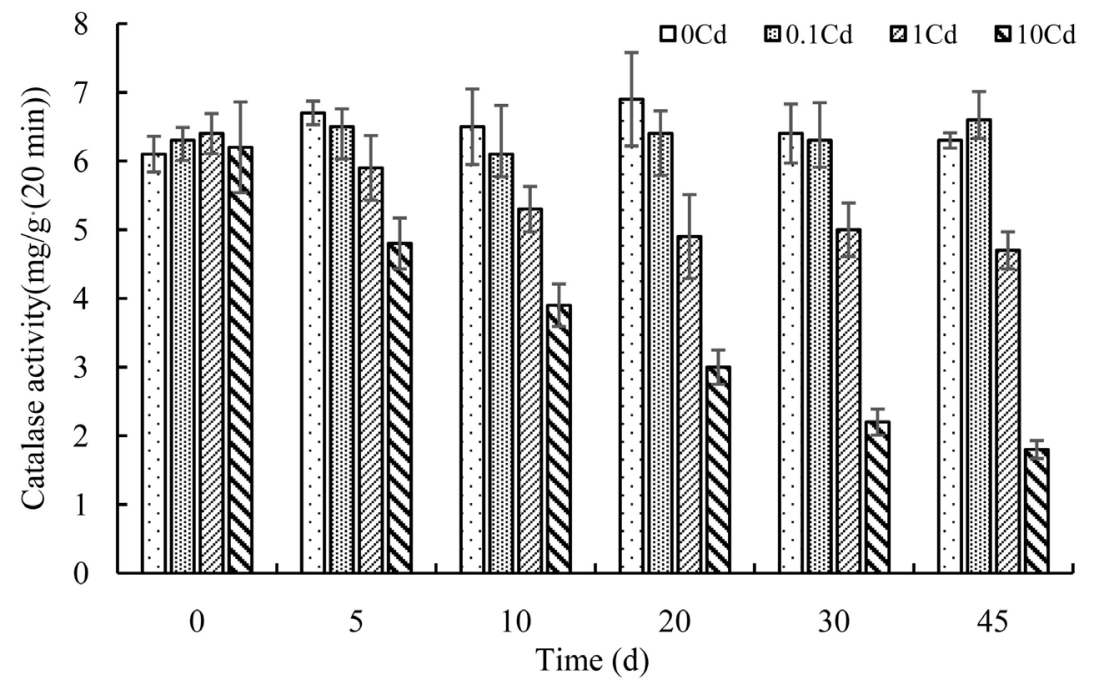

Figure 2. Effect of Cd concentrations on Catalase activity with time (d).

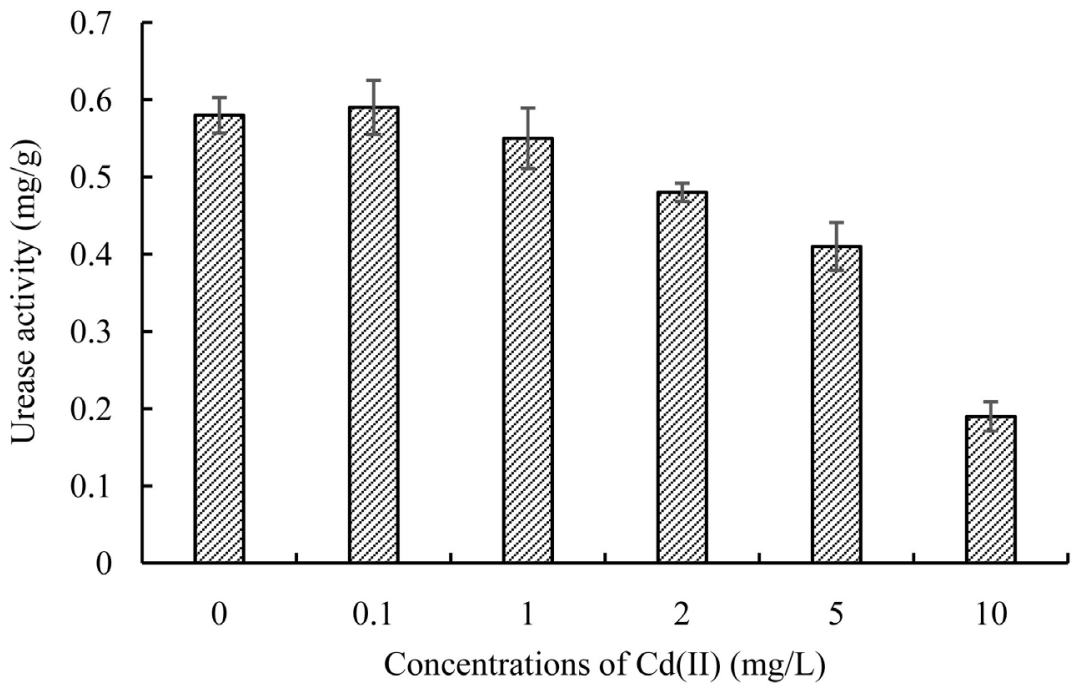

Figure 3. Effect of Cd concentrations on Urease activity in the soil. 


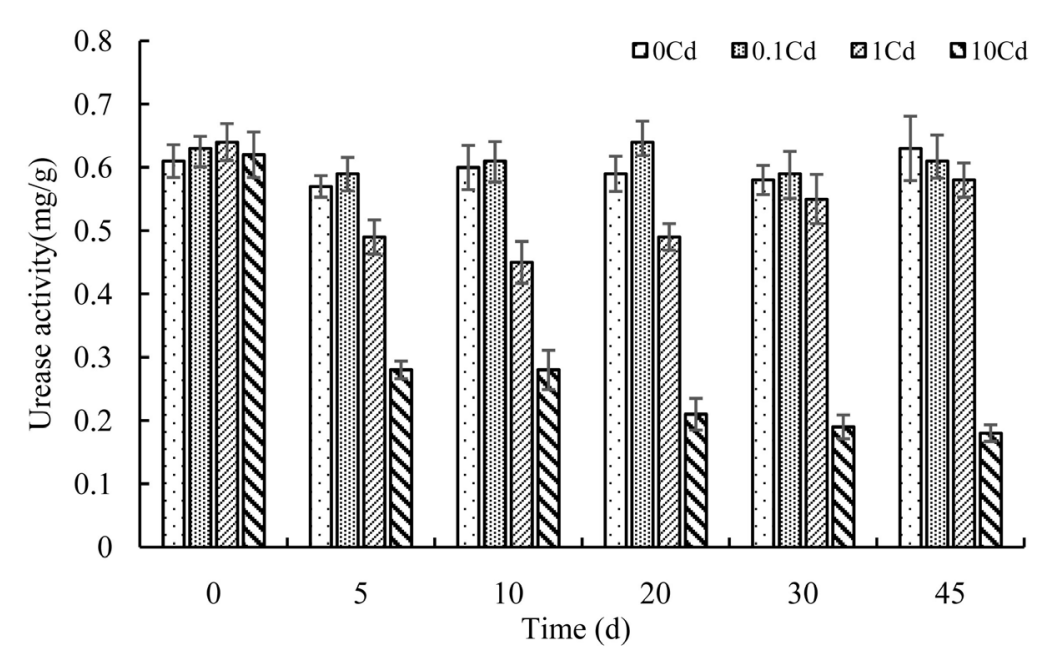

Figure 4. Effect of Cd concentrations on Urease activity with time (d).

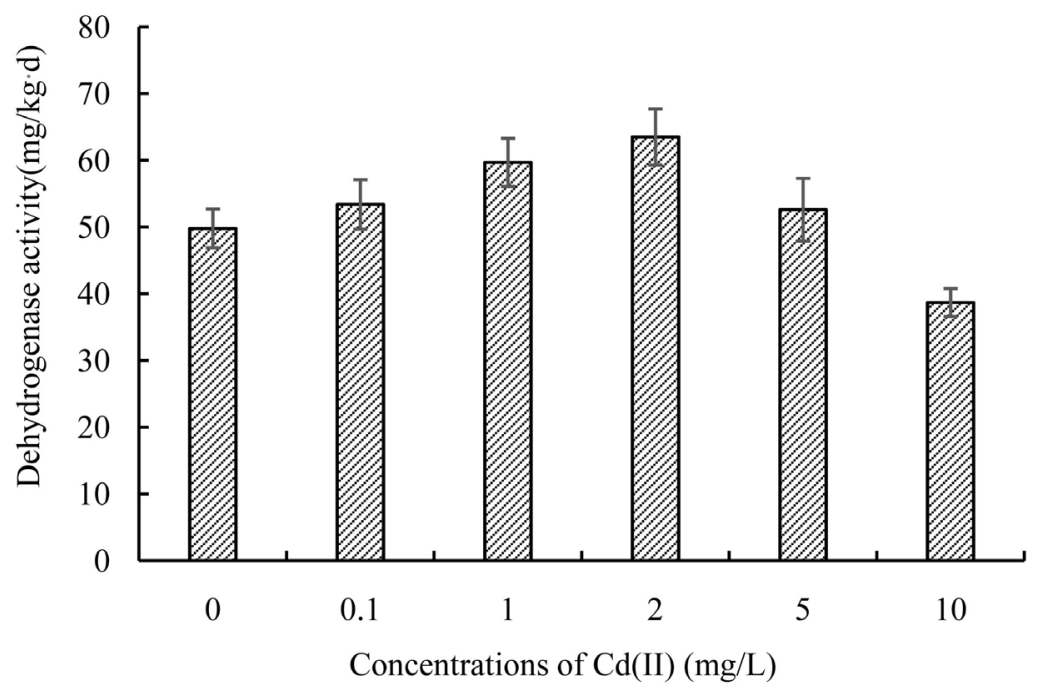

Figure 5. Effect of Cd concentrations on dehydrogenase activity in the soil.

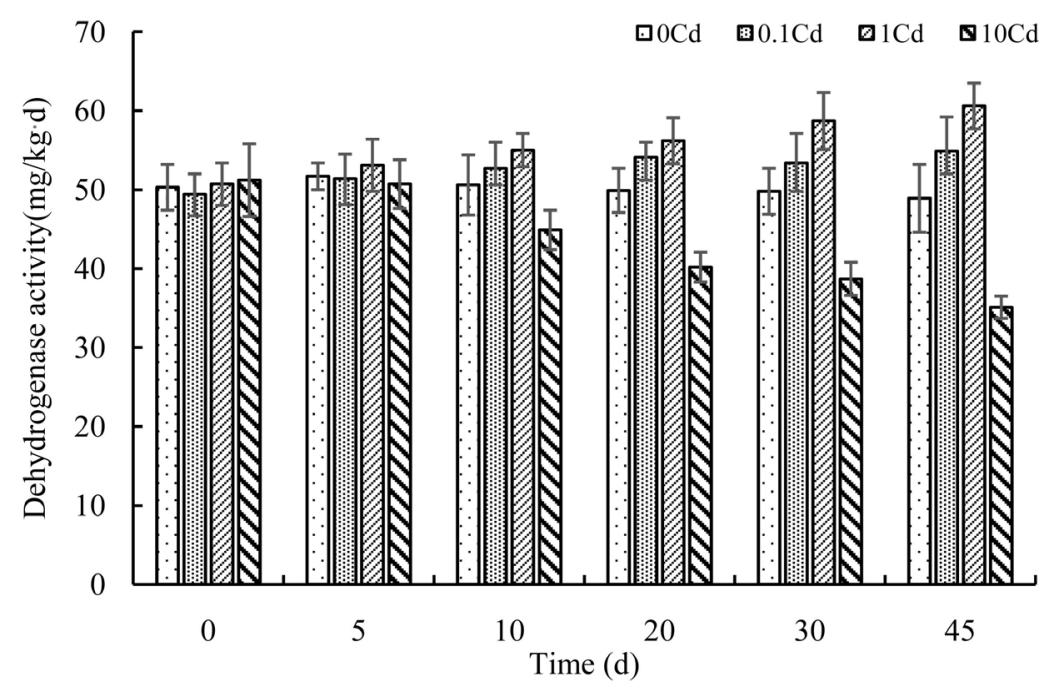

Figure 6. Effect of Cd concentrations on Dehydrogenase activity with time (d). 
management, agricultural activities, or contaminants on soil health, according to (Yang et al., 2016) in his report, is enzyme activity as stated by (Oleszczuk et al., 2014). Indirectly, enzymatic activities represent and display the ability to self-purify the soil affect by pollution (Cui et al., 2013a). The toxicological effects of $\mathrm{Cd}$ on the structure and activity of soil microbial communities are shown to be highly dependent on $\mathrm{Cd}$ content and incubation duration, according to this research. The inhibition degree of three enzymes' activities, Catalase, Urease, and Dehydrogenase, varied substantially between different incubation durations.

Before the 45-days incubation period, microbial activities such as catalase, urease, and dehydrogenase activity showed rapid inhibition, indicating that the microbes could react to $\mathrm{Cd}$ as well as other metals when exposed. The rise of soil microbial activity inhibition is likely to be linked to the microbial community's sensitivity and adaptation, pollutant concentrations, and the mechanisms and concentration intensity of Cadmium as heavy metal.

Catalase, Urease, and Dehydrogenase activity were determined before the reaction, with each having a unique method of testing, and then combined with various concentrations of Cadmium in the treated soil samples, leading to a reduction in enzymatic activity as Cadmium concentration increases. Toxicity of $\mathrm{Cd}, \mathrm{Cu}$, and $\mathrm{Pb}$ known as trace heavy metals have a significant impact on soil enzymatic activity, which was measured using the dehydrogenase and urease enzymes (Chaperon \& Sauvé, 2008).

It was discovered that metals resulted in reduction enzymatic activity and that the interaction of the metals occurs quickly enough to produce the observed results. According to the data collected, low cadmium concentrations did not affect enzyme activities, which would gradually decrease as cadmium concentrations rise, as will enzymatic activities. Influence on soil quality was found to affect soil enzymatic activities, soil respiration, and microbial abundance/biomass in previous studies (Bowles et al., 2014; Mbuthia et al., 2015). The most adverse influence of various contaminants related to soil health was estimated using soil enzymes such as soil urease activity, acid phosphatase activity, dehydrogenase activity, and catalase activity (Masto et al., 2009).

\subsection{Effect of Cadmium on Catalase Enzyme Activity of the Experiment}

\section{Cadmium concentration with catalase activity}

Catalase enzymes produce an anti-oxidant enzyme that breaks down hydrogen peroxide $\left(\mathrm{H}_{2} \mathrm{O}_{2}\right)$ into water and oxygen while avoiding the formation of free radicals. Catalase breaks down peroxide, and its behavior is influenced by soil dehydrogenase, amidase, glucosidase, and esterase activity, as well as organic oxygen concentration, microbe biomass, and $\mathrm{CO}_{2}$ shifts which enhances soil fertility (Burns et al., 2013). Figure 1 shows the effects of Cd increasing concentration on catalase activity: enzyme activity was unaffected at concentration of 0.1 $\mathrm{mg} / \mathrm{L}$, however it quickly decreased at higher concentrations, showing a clear detrimental effect of cadmium on enzyme activity. Catalase activity was inhi- 
bited in soils at the maximum Cd concentration levels. Excessive Cd concentrations were hazardous to microorganisms and had a higher impact on enzyme activities, with growing $\mathrm{Cd}$ concentrations in the soil reducing catalase activity.

Cadmium concentration and catalase activity are inversely and significantly related ( $\mathrm{r}=\mathrm{X}, \mathrm{df}=\mathrm{Y}, P<0.000 \mathrm{X})$, as previously observed by Yang et al. (2016). This demonstrates that $\mathrm{Cd}$, has a strong impact on soil catalase, confirming its toxicity on soil microorganisms (Shi \& Ma, 2017; Sun et al., 2016); causal relationship is attributable to microorganisms transferring the energy required for cell growth and maintenance to protection against toxicant effect of cadmium (Minnikova et al., 2017).

Heavy metals as contaminants interrelate with the enzyme-substrate complex, denature the enzyme, or interfere by protein active sites, resulting in decreased enzyme activity (Li et al., 2015). With an increase in Cd concentration and the loss of energy by Catalase enzymes due to the strain on the enzyme to sustain its cell, the process and activities in the soil gradually decrease. Catalase enzymatic activities decrease as the concentration rises with no additional nutrient or energy added to the soil.

\section{Cadmium concentration to time and days on catalase activity}

Several factors as $\mathrm{Cd}$ and soil type as well as climate influenced cadmium bioavailability (Dar, 1996; Dar \& Mishra, 1994), and persistence in the ground is another major parameter; In Figure 5, we can observe a clear relation between the time $\mathrm{Cd}$ remains in the soil and enzyme response intensity.

Figure 2 below gives data on different concentrations of $\mathrm{Cd}$ with time and days as the experiment took place. The concentrations of Cd that changed significantly were recorded; the images below show $\mathrm{Cd}$ concentrations that changed significantly with catalase enzymes throughout 0 to 45 days.

The concentration of $(0.0 .0 .1,1.010 .0) \mathrm{g} / \mathrm{mol}$ in 0 to 45 days had their respectively data readings on the catalase activity. For the same $\mathrm{Cd}$ concentration on day 10 of culturing, catalase activity displaced a slight shift in decrease. Chen et al. (2012) and Gao et al. (2010) discovered that soil catalase activities decline with the increasing availability of heavy metals, which as per the outcomes of this research as shown in Figure 4 as conditions remain constant for many days. The catalase activity does, however, increase as the day progresses. On $(10,20$, $30,45)$ days, $(0.0,0.1,1.0) \mathrm{mg} / \mathrm{L}$ concentrations had a separate reading of a rise and decrease in catalase activity as the days pass.

This may have been due to the enzymes' activities having too much energy to withstand the cell's pressure from the low concentration of $\mathrm{Cd}$ as heavy metal. As the low levels of $\mathrm{Cd}$ concentration remain constant, respiration and other enzymatic activities begin to take place within the cells of the enzymes, reducing the impact of low Cd levels. Catalase enzyme activity rises with declining extractable heavy metal concentrations, over time through direct and indirect mechanisms (Cui et al., 2013b; Hu et al., 2014; Papa et al., 2010; Yang et al., 2016).

For example, (Ahmad et al., 2012) discovered a negative link between enzyme activities and lead $(\mathrm{Pb})$ concentrations, as well as a similar showing of low $\mathrm{Cd}$ 
concentration with catalase activity and other enzymes $\mathrm{Hu}$ et al. (2014). In this study catalase, activity showed no significant correlation with the concentration of Cd with (0.0, 0.1, and 1.0) mg/L extractable heavy metals. (Hu et al., 2014) also observed that catalase, urease, and acid phosphatase activity was only slightly affected by heavy metal pollution when concentration was low.

\subsection{Effect of Cadmium on Urease Enzyme Activity of the Experiment}

\section{Cadmium concentration with Urease activity}

According to Fernandes et al. (2005) in reviewing Brookes, 1995, The influence of trace metals on soil microbial activities has been reviewed extensively as suggested by (Moreno et al., 2001) on urease enzyme activity. Urease activity in soil has the capacity of the enzyme to catalyze the transformation of urea into ammonium (Kandeler et al., 1999). And play a critical role in the global nitrogen cycle's mineralization step, catalyzing the rapid hydrolytic decomposition of urea to produce ammonia and carbamate, the latter of which decomposes spontaneously into a second molecule of ammonia and bicarbonate (Blakeley et al., 1969; Mazzei et al., 2020).

Urease activity $(0.58,0.59,0.55,0.49,0.41,0.19)$ was inhibited in soils at the maximum Cd concentration levels $(0.1,1,2,5,10)$ with urease activity $(0.58$, $0.59,0.55,0.49,0.41,0.19)$. High Cd levels demonstrated extreme toxicity against microorganisms, with rising $\mathrm{Cd}$ concentrations lowering urease activity.

From Figure 3, ammonia formed by the decomposition of urea into a second molecule of ammonia and bicarbonate in 24 hours was used to determine Urease activity (Blakeley et al., 1969; Mazzei et al., 2020), making Cadmium reaction effective on its activity. Higher levels of ammonia indicated higher urease activity, but an increase in Cd concentration affects Urease's respiration process, resulting in a gradual decrease in urease activity in the soil (Doelman \& Haanstra, 1986; Zheng et al., 2019). Since the sample with zero (0) concentration remains constant through the experiment days, there is a consistent decrease in urease activity in the soil samples, which usually suggests a diminishing trend with rising Cd concentration from day 1 of culturing as shown in the graph.

According to Doelman \& Haanstra (1986), after 6 weeks of incubation, there was a required increase in $\mathrm{Cd}$ concentration to induce a $10 \%$ decrease in urease activity, confirming that urease activity decreased dramatically from $0.58 \mathrm{mg} / \mathrm{g}$ to $0.19 \mathrm{mg} / \mathrm{g}$ as concentration increased from 0 to $10.0 \mathrm{mg} / \mathrm{L}$. Urease behaviours were found to be sensitive to the heavy metal Cd's inhibitory effect. Decreased enzyme synthesis is associated with restricted microbial growth due to loss of energy to repair cells rather than direct metal inhibition due to enzyme activities of biomass $\mathrm{C}$ in Cd-treated soils.

\section{Cadmium concentration with time (days) on Urease activity}

Mulvaney \& Bremner (1978) stated that Urease has been extensively studied about its inhibition by heavy metal as reported by Nor (1982). (Bremner \& Douglas, 1971) reported inhibition percentages of less than 5\% in two air-dried 
soils by adding $50 \mathrm{mg} \cdot \mathrm{kg}^{-1}, \mathrm{Cr} 3, \mathrm{Ni}$, and $\mathrm{Pb}$, while $\mathrm{Cu}$ caused inhibition of $13 \%$ 16\% (Tabatabai, 1977). The data on various concentrations of Cd with time and days on urease activity can be understood as the experiment takes in 45 days of this study. With Figure 4, the readings the sample with no Cd concentration or $0.0 \mathrm{~g} / \mathrm{mol}$ serving as the control experiment had little slight changes of reading with each day unfolding.

The various concentrations of $\mathrm{Cd}$ have a particular effect on urease function, as shown graphically in Figure 4. On day 10, soil urease activity in the soil showed a decreasing trend as $\mathrm{Cd}$ concentrations increased. Since the condition was not greatly affected by high concentration, urease activity was greater in the soil at a concentration of $0.0 \mathrm{mg} / \mathrm{L}$ than at a concentration of $10 \mathrm{mg} / \mathrm{L}$. According to (Zantua \& Bremner, 1975, 1977) urease activities and microbial biomass remain constant under these conditions for a very long time as reported by Nannipieri et al. (1983). Cd had a significant effect on urease activity at higher concentrations. Toxicity of Cd greatly reduced microbial abundance thus stimulating enzyme respiration. Regarding Moreno et al. (2001), the decrease in urease activity content or inhibition by $\mathrm{Cd}$ is due to the heavy metal's adverse effects on the activity of microbial species susceptible to $\mathrm{Cd}$ emissions reflecting on $10.0 \mathrm{mg} / \mathrm{L}$.

From day 10 to day 45, the concentrations of Cd $0.1 \mathrm{mg} / \mathrm{L}$ and $1.0 \mathrm{mg} / \mathrm{L}$ increase and decrease, indicating enzymatic activity. The increase and decrease of the readings shown in the graph indicate exhibiting a rise in energy to withstand the effect of Cd on enzymatic activity by a transformation of nitrogen in the soil (Adetunji et al., 2017; Makoi \& Ndakidemi, 2008). A high concentration of Cd $(10.0 \mathrm{mg} / \mathrm{L})$ had a significant impact on urease activity, putting additional strain on cell activities. This result corresponds to the outcome by Shi \& Ma (2017), who also indicates a report from Meng et al. (2018), discovering that mass fraction of heavy metals at low concentration, may enhance soil enzyme activity; a high mass fraction, influence soil enzyme activity excessively.

Aside from the long-term efficacy of $\mathrm{Cd}$ concentration on Urease production, an optimal stabilization of low concentrations has no major negative effects on the biological status of the soil (O'Connor et al., 2018; Tang et al., 2020). These results were in line with previous studies that reported that heavy metal content may affect soil enzyme activity by direct and indirect mechanisms (Cui et al., 2013b; Hu et al., 2014; Papa et al., 2010; Yang et al., 2016). For instance, stated by Ahmad et al. (2012), as reflected in Figure 4.

\subsection{Effect of Cadmium on Dehydrogenase Enzyme Activity}

Dehydrogenase enzymes transfer protons and electrons from substrates to accepters, which aids in the biological oxidation of soil organic matter (Tabatabai, 1982). DHA act as an indicator of microbial oxidative activities and microbiological redox systems (Dick et al., 1997; Von Mersi \& Schinner, 1991). Investigations by (Stevenson, 1959) have also shown, for certain Canadian soils, has is a strong as- 
sociation $(\mathrm{r}=0.84)$ between the reduction of 2,3,5,-triphenyltetrazoliumchloride (TTC) and $\mathrm{O}_{2}$ absorption $(\mathrm{r}=0.84)$ (Tabatabai, 1994) soils.

\section{Cadmium concentration with dehydrogenase activity}

Soil dehydrogenase activity correlates with biological activity and microbial communities in the soil. Intracellular dehydrogenase enzymes are oxidoreductases that catalyze organic compound oxidation by splitting two $\mathrm{H}$ atoms making Dehydrogenase activity a strong predictor of microbial oxidative activities in soils and it is also used for indicating microbiological redox systems (Tabatabai, 1982). Dehydrogenase activity $(48.0,53.0,59.7,63.5,52.6,38.7)$ was inhibited in soils at the maximum Cd concentrations $(00.1,1,2,5,10)$ with dehydrogenase activity $(48.0,53.0,59.7,63.5,52.6,38.7)$. High Cd levels exhibited extreme toxicity against microorganisms as $\mathrm{Cd}$ concentrations increased, lowering dehydrogenase activity in the soil.

China in 2014, recorded $10 \%$ to $20 \%$ of its soil been contaminated by heavy metals (Ye et al., 2014), of which Cd contamination being the most serious issues in arable land according to the Bulletin on National Survey of Soil Contamination, jointly issued in 2014 by the Ministry of Environmental Protection of China and Ministry of Land Resources of China. Dick, 1994; Dick et al. (1997) checked the effect of Cadmium on the soil microbial activity and at what concentration of $\mathrm{Cd}$ is considered to have more influence on dehydrogenase activity as shown in this study. Malley et al. (2006) discovered an overall reduction in dehydrogenase activity. Nweke et al. (2007) concluded that for all the metal ions $\left(\mathrm{Cd}^{2+}\right)$ there was progressive inhibition in dehydrogenase activity and rhizoplane microbial community with each successive increase in the concentration of metal ions. Cd had a strong active effect on the size of soil microbial biomass and Dehydrogenase enzyme activities.

From Figure 5, dehydrogenase activity increases with low concentration from $(0.0,0.1,1.0,2.0) \mathrm{mg} / \mathrm{L}$ with increase in the dehydrogenase activity $(49.8,53.4$, $59.7) \mathrm{mg} / \mathrm{kg}$. $\mathrm{d}$ as DHA releases energy to repair damaged cells by Cd. The readings show that a low concentration of $\mathrm{Cd}$ does not have a major significant effect on dehydrogenase activity. Interestingly the dehydrogenase activity shows an increase with increasing concentration of $\mathrm{Cd}$ of $(0.1,0,2.0) \mathrm{mg} / \mathrm{L}$ to dehydrogenase activity $(52.6,38.7) \mathrm{mg} / \mathrm{kg} . \mathrm{d}$. Dar (1996) reported a decrease in dehydrogenase activity (DHA) and alkaline phosphatase activity at $50 \mathrm{mg} \mathrm{Cd} \mathrm{kg}$ in a laboratory study with different soil types.

Landi et al. (2000) found a negative effect of Cd on DHA, but at a much higher concentration of $500 \mathrm{mg} \mathrm{Cd} \mathrm{kg}$ whereas dehydrogenase and acid phosphatase activity decreased at $50 \mathrm{mg} \mathrm{Cd} \mathrm{kg}$. The $\mathrm{Cd}$ concentration required to cause a similar inhibitory effect on phosphatase activity and DHA was 10 times greater in clay soil than in sandy soil (Doelman \& Haanstra, 1989). With this study, the Cd concentration needed to cause a similar inhibitory effect on dehydrogenase activity was $10.0 \mathrm{mg} / \mathrm{L}$ greater than its effect.

Cadmium concentration with time on dehydrogenase activity

Concentration of $(0.0 .0 .1,1.010 .0) \mathrm{g} / \mathrm{mol}$ in 0 to 45 days had their respective 
data readings on the dehydrogenase activity. Figure 6; below gives the readings of the sample with no Cd concentration or $0.0 \mathrm{~g} / \mathrm{mol}$ which serves as the control experiment that had slight changes of reading with each day unfolding.

Each data collected gives a clear definition of the influence of cadmium on the various enzymatic activities. Cd toxicity increased with the incubation time; therefore, the lowest microbial biomass and enzyme activity was observed at forty-five days of incubation. The results revealed that soil microbial biomass and enzyme activities were strongly inhibited by Cd. Rogers \& Li (1985). According to the graph, dehydrogenase activity increases with low concentrations from $(0.0,0.1,1.0) \mathrm{mg} / \mathrm{L}$, Tan et al. (2017) with a rise in dehydrogenase activity on (0 - 45) days with Cadmium incubation for days, low concentration of $\mathrm{Cd}$ does not have a major significant effect on dehydrogenase activity. Although the concentration of Cd rises from 0.0 to $1.0 \mathrm{mg} / \mathrm{L}$, which was supposed to negatively affect the Dehydrogenase activity, the respiratory soil properties transform to increase the dehydrogenase activity (Zheng et al., 2019).

Cd concentrations were increased, but the magnitudes of the decreases were not proportional to the Cd concentration added (Alef \& Kleiner, 1986; Casida, 1977; Tabatabai \& Bremner, 1969) as shown in Figure 6. Also in sludge amended soils, high Cd concentrations inhibited dehydrogenase, alkaline phosphatase, and arginine-ammonification activities, while low Cd concentrations increased dehydrogenase operation (Effron et al., 2004). The toxicity of Cd dehydrogenase activities decreased in soil with low $\mathrm{pH}$ (4.8) and high organic carbon (2.3\%) (Moreno et al., 2001). In addition, the basic enzymatic activities are striking and can be used to distinguish variations in dehydrogenase activity between the Cadmium concentrations (Tan et al., 2017; Tang et al., 2020; Xin et al., 2017).

\subsection{Comparing the Enzymatic Activities with Cadmium}

Comparably, the activities of urease, dehydrogenase and catalase differed significantly between treatments in this study, and the enzyme activities decreased as heavy metal concentrations increased. Heavy metals inhibited urease and dehydrogenase activity in general, supporting the findings of previous research (Wiatrowska et al., 2015; Xian et al., 2015). Other researchers explained, soil enzyme activities decrease with the increasing availability of heavy metals, Xian et al. (2015). Similarly, it was shown that Cd had a distinct inhibitory effect on urease, acid phosphatase, and catalase activities (Mao et al., 2015; Xin et al., 2017).

According to our findings, the order of sensitivity enzymes in response to Cadmium contamination is catalase $>$ urease $>$ dehydrogenase. Catalase activity decreased even when Cd levels were low, followed by Urease activity, and eventually dehydrogenase activity. The microbial community structure was heavily influenced in this study, which was consistent with lower microbial activities at various levels of $\mathrm{Cd}$ concentration and time. Furthermore, there was a significant community shift in this study, especially at high levels of Cd contamination, which is likely due to metal toxicity as well as nutrient scarcity because no nu- 
trients were provided during the incubation period (Khan et al., 2010).

The activities of Catalase, Urease, and Dehydrogenase were all affected by Cd contamination. Each soil enzyme is sensitive to heavy metals in a different way Sethi \& Gupta (2015); Shen et al. (2005); Shen et al. (2005). Urease and dehydrogenase can be useful indicators of combined pollution heavy metals, particularly in the early stages of pollution, according to a study, Sethi \& Gupta (2015), Yang et al. (2016). Our findings for soil respiration may be used to estimate the capacity for heavy metals in polluted field soils to adversely impact soil microbial group responses, and soil respiration activity was close to that of the microbe population under $\mathrm{Cd}$.

\section{Conclusion}

It is well known that cadmium emission reduces the biological activity of soil microorganisms. Soil enzyme activity may be used as a metric to measure the impact of heavy metals on biological activity in the soil. In soil, catalase and urease are sensitive to heavy metals, including $\mathrm{Cd}$, and can represent heavy metal toxicity on soil microorganisms. Enzymatic activity declines have been linked to soil metal load by the majority of researchers. Also, different soil enzymes responded differently to elevated heavy metal concentrations. Soils with the highest concentrations of $\mathrm{Cd}$ had the lowest levels of soil enzyme activity.

As a result, decreases in microbial populations have been reported in the soils polluted with heavy metal compounds. In addition, heavy metal pollution can inhibit or even destroy sensitive soil microorganisms, associated with decreased soil respiration and enzyme activity with increasing Cadmium levels. Gradual changes in enzymatic community composition were observed in this study as a result of $\mathrm{Cd}$ gradients, suggesting the existence of dose-related effects, as previously stated.

Heavy metals can inhibit enzyme activity by interfering with the enzymesubstrate complex, denaturing the enzyme protein, and interfering with the active sites, or by interfering with the microbial cells' ability to synthesize enzymes. Changes in the group structure caused by metals may also affect enzyme activity. Heavy metal toxicity induced the death of a large number of microorganisms, and the surviving microorganisms required energy supply for survival and resistance to heavy metal toxicity.

Enzymes including Catalase, Urease, Dehydrogenase, and Alkaline Phosphatase, as well as other enzymatic activities, are inactivated when $\mathrm{Cd}$ binds to active sites, causing metabolism to be disrupted. Cadmium, in addition to being an enzyme inhibitor, can harm membrane structure and function by binding to ligands including phosphate and protein cysteinyl and histidyl groups.

The following conclusion of $\mathrm{Cd}$ in relation with time, concentration among these enzyme activities (Catalase, Urease, and Dehydrogenase) are listed below:

- High Cd concentrations influenced the activity of soil enzymes catalase, urease, and dehydrogenase. When $\mathrm{Cd}$ concentrations were poor, the total 
metal content and enzyme activity had a weak effect on the enzymes.

- There are significant variations in the activity of Catalase, Urease, and Dehydrogenase enzymes, with dehydrogenase activity increasing with lower Cd concentrations.

- Cadmium is classified as a class 1 human carcinogen, although a weak genotoxic has been identified as a hazardous element contaminate to soil enzyme activities by various researchers. As a result, the enzymes studied in this study can be grouped according to their sensitivity to $\mathrm{Cd}$ : catalase $>$ urease $>$ dehydrogenases.

\section{Acknowledgements}

A special thanks to Professor SHI Weilin, SHI Guang-yu and the Suzhou Universities' Administration for their tireless work during my studies in the University and for helping me put these essential pieces of writing together. Also, appreciation goes to TSP and the Chinese Government for funding this scholarship to make these academic endeavours happening. Finally, I acknowledge all the individuals and professionals who assisted in one way or the other to achieve this goal.

\section{Conflicts of Interest}

The authors declare no conflicts of interest regarding the publication of this paper.

\section{References}

Adetunji, A. T., Lewu, F. B., Mulidzi, R., \& Ncube, B. (2017). The Biological Activities of $\beta$-Glucosidase, Phosphatase and Urease as Soil Quality Indicators: A Review. Journal of Soil Science and Plant Nutrition, 17, 794-807. https://doi.org/10.4067/S0718-95162017000300018

Ahmad, M., Hashimoto, Y., Moon, D. H., Lee, S. S., \& Ok, Y. S. (2012). Immobilization of Lead in a Korean Military Shooting Range Soil Using Eggshell Waste: An Integrated Mechanistic Approach. Journal of Hazardous Materials, 209, 392-401.

https://doi.org/10.1016/j.jhazmat.2012.01.047

Ahmad, Z., Gao, B., Mosa, A., Yu, H., Yin, X., Bashir, A., Ghoveisi, H., \& Wang, S. (2018). Removal of $\mathrm{Cu}$ (II), Cd (II) and Pb (II) Ions from Aqueous Solutions by Biochars Derived from Potassium-Rich Biomass. Journal of Cleaner Production, 180, 437-449. https://doi.org/10.1016/j.jclepro.2018.01.133

Alef, K., \& Kleiner, D. (1986). Arginine Ammonification, a Simple Method to Estimate Microbial Activity Potentials in Soils. Soil Biology and Biochemistry, 18, 233-235. https://doi.org/10.1016/0038-0717(86)90033-7

Blakeley, R. L., Hinds, J. A., Kunze, H. E., Webb, E. C., \& Zerner, B. (1969). Jack Bean Urease (EC 3.5.1.5). Demonstration of a Carbamoyl-Transfer Reaction and Inhibition by Hydroxamic Acids. Biochemistry, 8, 1991-2000.

https://doi.org/10.1021/bi00833a032

Bowles, T. M., Acosta-Martínez, V., Calderón, F., \& Jackson, L. E. (2014). Soil Enzyme Activities, Microbial Communities, and Carbon and Nitrogen Availability in Organic Agroecosystems across an Intensively Managed Agricultural Landscape. Soil Biology 
and Biochemistry, 68, 252-262. https://doi.org/10.1016/j.soilbio.2013.10.004

Bremner, J. M., \& Douglas, L. A. (1971). Inhibition of Urease Activity in Soils. Soil Biology and Biochemistry, 3, 297-307. https://doi.org/10.1016/0038-0717(71)90039-3

Burns, R. G., DeForest, J. L., Marxsen, J., Sinsabaugh, R. L., Stromberger, M. E., Wallenstein, M. D., Weintraub, M. N., \& Zoppini, A. (2013). Soil Enzymes in a Changing Environment: Current Knowledge and Future Directions. Soil Biology and Biochemistry, 58, 216-234.

Casida, L. E. (1977). Microbial Metabolic Activity in Soil as Measured by Dehydrogenase Determinations. Applied and Environmental Microbiology, 34, 630-636. https://doi.org/10.1128/aem.34.6.630-636.1977

Chaperon, S., \& Sauvé, S. (2008). Toxicity Interactions of Cadmium, Copper, and Lead on Soil Urease and Dehydrogenase Activity with Chemical Speciation. Ecotoxicology and Environmental Safety, 70, 1-9. https://doi.org/10.1016/j.ecoenv.2007.10.026

Chen, S., Gu, J., Fu, Q., Sun, W., Qian, X., Gao, H., \& Qin, Q. (2012). Effects of Azotobacter Inoculation on Soil Enzyme Activities and Bacterial Community Functional Diversity in the Rhizosphere of Maize (Zea mays L.). Plant Nutrition and Fertilizer Science, 18, 444-450.

Cofie, O., Rao, K., Paul, J., \& Fernando, S. (2014). Composting Experience in Developing Countries: Drivers and Constraints for Composting Development in Ghana, India, Bangladesh and Sri Lanka (p. 154).

Cui, H., Zhou, J., Zhao, Q., Si, Y., Mao, J., Fang, G., \& Liang, J. (2013a). Fractions of Cu, Cd, and Enzyme Activities in Contaminated Soil as Affected by Applications of Microand Nanohydroxyapatite. Journal of Soils and Sediments, 13, 742-752.

https://doi.org/10.1007/s11368-013-0654-x

Cui, L., Yan, J., Yang, Y., Li, L., Quan, G., Ding, C., Chen, T., Fu, Q., \& Chang, A. (2013b). Influence of Biochar on Microbial Activities of Heavy Metals Contaminated Paddy Fields. BioResources, 8, 5536-5548.

https://doi.org/10.15376/biores.8.4.5536-5548

Dar, G. H. (1996). Effects of Cadmium and Sewage-Sludge on Soil Microbial Biomass and Enzyme Activities. Bioresource Technology, 56, 141-145. https://doi.org/10.1016/0960-8524(95)00186-7

Dar, G. H., \& Mishra, M. M. (1994). Influence of Cadmium on Carbon and Nitrogen Mineralization in Sewage Sludge Amended Soils. Environmental Pollution, 84, 285-290. https://doi.org/10.1016/0269-7491(94)90140-6

Dick, R. P. (1994). Soil Enzyme Activities as Indicators of Soil Quality. Defining Soil Quality for a Sustainable Environment, 35, 107-124. https://doi.org/10.2136/sssaspecpub35.c7

Dick, R. P., Breakwell, D. P., \& Turco, R. F. (1997). Soil Enzyme Activities and Biodiversity Measurements as Integrative Microbiological Indicators. Methods for Assessing Soil Quality, 49, 247-271. https://doi.org/10.2136/sssaspecpub49.c15

Doelman, P., \& Haanstra, L. (1986). Short- and Long-Term Effects of Heavy Metals on Urease Activity in Soils. Biology and Fertility of Soils, 2, 213-218. https://doi.org/10.1007/BF00260846

Doelman, P., \& Haanstra, L. (1989). Short- and Long-Term Effects of Heavy Metals on Phosphatase Activity in Soils: An Ecological Dose-Response Model Approach. Biology and Fertility of Soils, 8, 235-241. https://doi.org/10.1007/BF00266485

Effron, D., De la Horra, A. M., Defrieri, R. L., Fontanive, V., \& Palma, R. M. (2004). Effect of Cadmium, Copper, and Lead on Different Enzyme Activities in a Native Forest Soil. Communications in Soil Science and Plant Analysis, 35, 1309-1321. 
https://doi.org/10.1081/CSS-120037548

Fabietti, G., Biasioli, M., Barberis, R., \& Ajmone-Marsan, F. (2010). Soil Contamination by Organic and Inorganic Pollutants at the Regional Scale: The Case of Piedmont, Italy. Journal of Soils and Sediments, 10, 290-300. https://doi.org/10.1007/s11368-009-0114-9

Fernandes, S. A. P., Bettiol, W., \& Cerri, C. C. (2005). Effect of Sewage Sludge on Microbial Biomass, Basal Respiration, Metabolic Quotient and Soil Enzymatic Activity. Applied Soil Ecology, 30, 65-77. https://doi.org/10.1016/j.apsoil.2004.03.008

Gao, Y., Zhou, P., Mao, L., Zhi, Y., \& Shi, W. (2010). Assessment of Effects of Heavy Metals Combined Pollution on Soil Enzyme Activities and Microbial Community Structure: Modified Ecological Dose-Response Model and PCR-RAPD. Environmental Earth Sciences, 60, 603-612. https://doi.org/10.1007/s12665-009-0200-8

Guan, S. Y. (1986). Soil Enzyme and Its Research Approach. Beijing: China Agriculture Press.

Guan, S. Y., Zhang, D., \& Zhang, Z. (1986). Soil Enzyme and Its Research Methods (pp. 274-297). Beijing: Chinese Agricultural Press.

Hu, X.-F., Jiang, Y., Shu, Y., Hu, X., Liu, L., \& Luo, F. (2014). Effects of Mining Wastewater Discharge on Heavy Metal Pollution and Soil Enzyme Activity of the Paddy Fields. Journal of Geochemical Exploration, 147, 139-150.

https://doi.org/10.1016/j.gexplo.2014.08.001

Kandeler, E., Stemmer, M., Palli, S., \& Gerzabek, M. H. (1999). Xylanase, Invertase and Urease Activity in Particle-Size Fractions of Soils. In Effect of Mineral-Organic-Microorganism Interactions on Soil and Freshwater Environments (pp. 275-286). Berlin: Springer. https://doi.org/10.1007/978-1-4615-4683-2 30

Kandeler, F., Kampichler, C., \& Horak, O. (1996). Influence of Heavy Metals on the Functional Diversity of Soil Microbial Communities. Biology and Fertility of Soils, 23, 299-306. https://doi.org/10.1007/BF00335958

Khan, S., Hesham, A. E.-L., Qiao, M., Rehman, S., \& He, J.-Z. (2010). Effects of Cd and Pb on Soil Microbial Community Structure and Activities. Environmental Science and Pollution Research, 17, 288-296. https://doi.org/10.1007/s11356-009-0134-4

Krčmar, D., Tenodi, S., Grba, N., Kerkez, D., Watson, M., Rončević, S., \& Dalmacija, B. (2018). Preremedial Assessment of the Municipal Landfill Pollution Impact on Soil and Shallow Groundwater in Subotica, Serbia. Science of the Total Environment, 615, 1341-1354. https://doi.org/10.1016/j.scitotenv.2017.09.283

Landi, L., Renella, G., Moreno, J. L., Falchini, L., \& Nannipieri, P. (2000). Influence of Cadmium on the Metabolic Quotient, L-: D-glutamic Acid Respiration Ratio and Enzyme Activity: Microbial Biomass Ratio under Laboratory Conditions. Biology and Fertility of Soils, 32, 8-16. https://doi.org/10.1007/s003740000205

Li, Q., Liu, H., Alattar, M., Jiang, S., Han, J., Ma, Y., \& Jiang, C. (2015). The Preferential Accumulation of Heavy Metals in Different Tissues Following Frequent Respiratory Exposure to PM 2.5 in Rats. Scientific Reports, 5, Article No. 16936. https://doi.org/10.1038/srep16936

Makoi, J. H. J. R., \& Ndakidemi, P. A. (2008). Selected Soil Enzymes: Examples of Their Potential Roles in the Ecosystem. African Journal of Biotechnology, 7, 181-191.

Malley, C., Nair, J., \& Ho, G. (2006). Impact of Heavy Metals on the Enzymatic Activity of Substrate and on Composting Worms Eisenia fetida. Bioresource Technology, 97, 1498-1502. https://doi.org/10.1016/j.biortech.2005.06.012

Mao, L., Tang, D., Feng, H., Gao, Y., Zhou, P., Xu, L., \& Wang, L. (2015). Determining Soil Enzyme Activities for the Assessment of Fungi and Citric Acid-Assisted Phytoextraction under Cadmium and Lead Contamination. Environmental Science and Pollu- 
tion Research, 22, 19860-19869.

Masto, R. E., Chhonkar, P. K., Singh, D., \& Patra, A. K. (2009). Changes in Soil Quality Indicators under Long-Term Sewage Irrigation in a Sub-Tropical Environment. Environmental Geology, 56, 1237-1243. https://doi.org/10.1007/s00254-008-1223-2

Mazzei, L., Musiani, F., \& Ciurli, S. (2020). The Structure-Based Reaction Mechanism of Urease, a Nickel Dependent Enzyme: A Tale of a Long Debate. JBIC Journal of Biological Inorganic Chemistry, 1-17. https://doi.org/10.1007/s00775-020-01808-w

Mbuthia, L. W., Acosta-Martínez, V., DeBruyn, J., Schaeffer, S., Tyler, D., Odoi, E., Mpheshea, M., Walker, F., \& Eash, N. (2015). Long Term Tillage, Cover Crop, and Fertilization Effects on Microbial Community Structure, Activity: Implications for Soil Quality. Soil Biology and Biochemistry, 89, 24-34.

https://doi.org/10.1016/j.soilbio.2015.06.016

Meng, X., Ai, Y., Li, R., \& Zhang, W. (2018). Effects of Heavy Metal Pollution on Enzyme Activities in Railway Cut Slope Soils. Environmental Monitoring and Assessment, 190, 19.

Minnikova, T. V., Denisova, T. V., Mandzhieva, S. S., Kolesnikov, S. I., Minkina, T. M., Chaplygin, V. A., Burachevskaya, M. V., Sushkova, S. N., \& Bauer, T. V. (2017). Assessing the Effect of Heavy Metals from the Novocherkassk Power Station Emissions on the Biological Activity of Soils in the Adjacent Areas. Journal of Geochemical EXploration, 174, 70-78. https://doi.org/10.1016/j.gexplo.2016.06.007

Moreno, J. L., Garcia, C., Landi, L., Falchini, L., Pietramellara, G., \& Nannipieri, P. (2001). The Ecological Dose Value (ED50) for Assessing Cd Toxicity on ATP Content and Dehydrogenase and Urease Activities of Soil. Soil Biology and Biochemistry, 33, 483-489. https://doi.org/10.1016/S0038-0717(00)00189-9

Mulvaney, R. L., \& Bremner, J. M. (1978). Use of p-Benzoquinone and Hydroquinone for Retardation of Urea Hydrolysis in Soils. Soil Biology and Biochemistry, 10, 297-302. https://doi.org/10.1016/0038-0717(78)90026-3

Nannipieri, P., Muccini, L., \& Ciardi, C. (1983). Microbial Biomass and Enzyme Activities: Production and Persistence. Soil Biology and Biochemistry, 15, 679-685. https://doi.org/10.1016/0038-0717(83)90032-9

Nor, Y. M. (1982). Soil Urease Activity and Kinetics. Soil Biology and Biochemistry, 14, 63-65. https://doi.org/10.1016/0038-0717(82)90078-5

Nweke, C. O., Ntinugwa, C., Obah, I. F., Ike, S. C., Eme, G. E., Opara, E. C., Okolo, J. C., \& Nwanyanwu, C. E. (2007). In Vitro Effects of Metals and Pesticides on Dehydrogenase Activity in the Microbial Community of Cowpea (Vigna unguiculata) Rhizoplane. African Journal of Biotechnology, 6, 290-295.

O’Connor, D., Peng, T., Zhang, J., Tsang, D. C. W., Alessi, D. S., Shen, Z., Bolan, N. S., \& Hou, D. (2018). Biochar Application for the Remediation of Heavy Metal Polluted Land: A Review of in Situ Field Trials. Science of the Total Environment, 619, 815-826. https://doi.org/10.1016/j.scitotenv.2017.11.132

Oleszczuk, P., Jośko, I., Futa, B., Pasieczna-Patkowska, S., Pałys, E., \& Kraska, P. (2014). Effect of Pesticides on Microorganisms, Enzymatic Activity and Plant in BiocharAmended Soil. Geoderma, 214, 10-18. https://doi.org/10.1016/j.geoderma.2013.10.010

Papa, S., Bartoli, G., Pellegrino, A., \& Fioretto, A. (2010). Microbial Activities and Trace Element Contents in Urban Soil. Environmental Monitoring and Assessment, 165, 193-203. https://doi.org/10.1007/s10661-009-0938-1

Rogers, J. E., \& Li, S. W. (1985). Effect of Metals and Other Inorganic Ions on Soil Micro- 
bial Activity: Soil Dehydrogenase Assay as a Simple Toxicity Test. Bulletin of Environmental Contamination and Toxicology, 34, 858-865. https://doi.org/10.1007/BF01609817

Sethi, S., \& Gupta, S. (2015). Responses of Soil Enzymes to Different Heavy Metals. Biolife, 3, 147-153.

Shen, G., Lu, Y., Zhou, Q., \& Hong, J. (2005). Interaction of Polycyclic Aromatic Hydrocarbons and Heavy Metals on Soil Enzyme. Chemosphere, 61, 1175-1182. https://doi.org/10.1016/j.chemosphere.2005.02.074

Shi, W., \& Ma, X. (2017). Effects of Heavy Metal Cd Pollution on Microbial Activities in Soil. Annals of Agricultural and Environmental Medicine, 24, 722-725. https://doi.org/10.26444/aaem/80920

Stevenson, I. L. (1959). Dehydrogenase Activity in Soils. Canadian Journal of Microbiology, 5, 229-235. https://doi.org/10.1139/m59-026

Sun, Y., Zhao, D., Xu, Y., Wang, L., Liang, X., \& Shen, Y. (2016). Effects of Sepiolite on Stabilization Remediation of Heavy Metal-Contaminated Soil and Its Ecological Evaluation. Frontiers of Environmental Science \& Engineering, 10, 85-92. https://doi.org/10.1007/s11783-014-0689-2

Tabatabai, M. A. (1977). Effects of Trace Elements on Urease Activity in Soils. Soil Biology and Biochemistry, 9, 9-13. https://doi.org/10.1016/0038-0717(77)90054-2

Tabatabai, M. A. (1982). Soil Enzymes. In A. L. Page (Ed.), Methods of Soil Analysis, Part 2. Chemical and Microbiological Properties (pp. 1-26). Agronomy 9, Madison, WI: The American Society of Agronomy.

Tabatabai, M. A. (1994). Soil Enzymes. In A. L. Page (Ed.), Methods of Soil Analysis: Part 2 Microbiological and Biochemical Properties (pp. 775-833). Madison, WI: The American Society of Agronomy. https://doi.org/10.2136/sssabookser5.2.c37

Tabatabai, M. A., \& Bremner, J. M. (1969). Use of p-Nitrophenyl Phosphate for Assay of Soil Phosphatase Activity. Soil Biology and Biochemistry, 1, 301-307. https://doi.org/10.1016/0038-0717(69)90012-1

Tan, X., Liu, Y., Yan, K., Wang, Z., Lu, G., He, Y., \& He, W. (2017). Differences in the Response of Soil Dehydrogenase Activity to Cd Contamination are Determined by the Different Substrates Used for Its Determination. Chemosphere, 169, 324-332. https://doi.org/10.1016/j.chemosphere.2016.11.076

Tang, J., Zhang, L., Zhang, J., Ren, L., Zhou, Y., Zheng, Y., Luo, L., Yang, Y., Huang, H., \& Chen, A. (2020). Physicochemical Features, Metal Availability and Enzyme Activity in Heavy Metal-Polluted Soil Remediated by Biochar and Compost. Science of the Total Environment, 701, Article ID: 134751.

https://doi.org/10.1016/j.scitotenv.2019.134751

Von Mersi, W., \& Schinner, F. (1991). An Improved and Accurate Method for Determining the Dehydrogenase Activity of Soils with Iodonitrotetrazolium Chloride. Biology and Fertility of Soils, 11, 216-220. https://doi.org/10.1007/BF00335770

Wiatrowska, K., Komisarek, J., \& Dluzewski, P. (2015). Effects of Heavy Metals on the Activity of Dehydrogenases, Phosphatases and Urease in Naturally and Artificially Contaminated Soils. Journal of Elementology, 20, No. 3.

Xian, Y., Wang, M., \& Chen, W. (2015). Quantitative Assessment on Soil Enzyme Activities of Heavy Metal Contaminated Soils with Various Soil Properties. Chemosphere, 139, 604-608.

Xin, J., Zhao, X., Tan, Q., Sun, X., Wen, X., Qin, S., \& Hu, C. (2017). The Effects of Cadmium Exposure on Cadmium Fractionation and Enzyme Activities in the Rhizosphere 
of Two Radish Cultivars (Raphanus sativus L.). Bulletin of Environmental Contamination and Toxicology, 98, 290-295. https://doi.org/10.1007/s00128-016-1998-X

Xu, Y. X., Du, A. P., Wang, Z. C., Zhu, W. K., Li, C., \& Wu, L. C. (2020). Effects of Different Rotation Periods of Eucalyptus Plantations on Soil Physiochemical Properties, Enzyme Activities, Microbial Biomass and Microbial Community Structure and Diversity. Forest Ecology and Management, 456, Article ID: 117683.

Yang, X., Liu, J., McGrouther, K., Huang, H., Lu, K., Guo, X., He, L., Lin, X., Che, L., \& Ye, Z. (2016). Effect of Biochar on the Extractability of Heavy Metals (Cd, Cu, Pb, and $\mathrm{Zn}$ ) and Enzyme Activity in the Soil. Environmental Science and Pollution Research, 23, 974-984. https://doi.org/10.1007/s11356-015-4233-0

Ye, X., Li, H., Ma, Y., Wu, L., \& Sun, B. (2014). The Bioaccumulation of Cd in Rice Grains in Paddy Soils Is Affected and Predicted by Soil Properties. Journal of Soils and Sediments, 14, 1407-1416. https://doi.org/10.1007/s11368-014-0901-9

Zantua, M. I., \& Bremner, J. M. (1975). Preservation of Soil Samples for Assay of Urease Activity. Soil Biology and Biochemistry, 7, 297-299. https://doi.org/10.1016/0038-0717(75)90070-X

Zantua, M. I., \& Bremner, J. M. (1977). Stability of Urease in Soils. Soil Biology and Biochemistry, 9, 135-140. https://doi.org/10.1016/0038-0717(77)90050-5

Zheng, L., Li, Y., Shang, W., Dong, X., Tang, Q., \& Cheng, H. (2019). The Inhibitory Effect of Cadmium and/or Mercury on Soil Enzyme Activity, Basal Respiration, and Microbial Community Structure in a Coal Mine-Affected Agricultural Soil. Annals of Microbiology, 69, 849-859. https://doi.org/10.1007/s13213-019-01478-3

Zhou, L. K., \& Zhang, Z. M. (1980). The Determination Method of Soil Enzyme Activity. Agrology, 5, 37-41. 